\title{
20 VUOTTA PUGWASH-LIIKETTÄ
}

ta: "Keskiraskaan tähden kehitys hapen palamisen vaiheeseen saakka" ja "Heliumista muodostuneen valkoisen kääpiön kehitys sen kerätessä ainetta toisesta komponentista". Molemmat tutkimukset toivomme saavamme päätökseen toisen suomalais-neuvostoliittolaisen kokouksen alkuun mennessä.

Tämä kokous pidetään Abastumanissa syyskuussa tänä vuonna. Ensimmäinen suomalais-neuvostoliittolainen kokous pidettiin vuonna 1975 Helsingissä. Yhteisissä kokouksissa konkretisoimme tutkimussuunnitelmia seuraavan kahden vuoden ajaksi, käsittelemme yhteisten tutkimusten toteuttamista ja tuloksia jne. Tällainen yhteistyön muoto, pitempiaikaisten vierailujen lisäksi, on hyvin hedelmällinen ja auttaa parantamaan ja laajentamaan yhteistyötä.

Ene Ergma
20 vuotta sitten, heinäkuussa 1957 kokoontui pienessä Pugwashin kalastajakylässä Kanadan Nova Scotiassa, amerikkalais-kanadalaisen monimiljonääri Cyrus Eatonin maatilalla 22 tiedemiestä, mukana useita Nobelin palkinnon saaneita: fyysikkoja, kemistejä, biologeja ja yksi lakimies. Tiedemiehet tulivat USA:sta, Neuvostoliitosta, Japanista, Englannista, Kanadasta, Australiasta, Kiinasta, Ranskasta, Itävallasta ja Puolasta. Kokouksen aiheina olivat ydinsodan vaarat, ydinasekokeiden kieltäminen ja tiedemiesten yhteiskunnallinen vastuu. Kokouksesta sai alkunsa Pugwash-liikkeen nimellä tunnettu kansainvälinen atomiaseita ja asevarustelua vastustava tiedemiesten järjestö ja konferenssisarja.

Ensimmäisenä ajatuksen tällaisen järjestön muodostamisesta esitti Bertrand Russell jo vuonna 1945. Tuon vuoden marraskuussa Russell esitti Englannin parlamentin ylähuoneessa pitämässään puheessa lännen ja idän tiedemiesten tapaamista, jossa pitäisi käsitellä, miten voitaisiin estää kansainvälisen kontrollijärjestelmän avulla ydinsodan puhkeaminen.

Russellin ehdotus ei johtanut välittömästi konkreettisiin toimenpiteisiin, mutta sen suuntaista kehitystä kuitenkin tapahtui. Lontoossa perustettiin 1946 Maailman tiedetyöntekijäin liitto (WFSW) taustahahmonaan erityisesti John D. Bernal (ks. tarkemmin Risto Eräsaari, WFSW 30 vuotta, Tiede ja edistys 1/77). Yhdysvalloissa ja Englannissa syntyivät atomialan tieteenharjoittajain yhdistykset. Saman liikkeen tuloksena syntyi tieteellinen aikakauslehti Bulletin of the Atomic Scientists, jonka päätoimittajana on ollut perustamisesta lähtien ydinfyysikko Eugene Rabinovich.

Kysymys, joka roikkui ilmassa, kuului: mikä on tiedemiesten moraalinen ja yhteiskunnallinen vastuu heidän keksintöjensä soveltamisesta ja käyttämisestä sodan välineenä?

Ydinfyysikot Leo Szilard ja
Albert Einstein olivat syksyllä 1939 ehdottaneet presidentti Rooseveltille atomipommin kehittämistä: he tahtoivat liittoutuneiden ehtivän Hitlerin edelle. Saksan antauduttua ilmeni, ettei Hitlerillä ollutkaan atomipommin kehittämisen ohjelmaa, ja kaksi ensimmäistä atomipommia käytettiinkin kahden siviilikaupungin tuhoamiseen.

Asetta kehittämässä olleet ydinfyysikot ja yleensä tiedemiehet kokivat voimakkaan moraalisen järkytyksen. Hiroshiman ja Nagasakin pommitukset olivat "ensimmäinen diplomaattinen operaatio kylmässä sodassa", kuten englantilainen fyysikko P.M.S. B 1 a c $k$ e t $t$ on todennut. (Jorma Lindfors, Jännityksen lieveneminen ja aseistariisunta, Soihtu 1/77) Hitleriä pakoon lähtenyt, sittemmin Nobelpalkinnon saanut ydinfyysikko Max Born kirjoitti: Moderni fysiikka ei ole enää "hiljainen, puhdas vanhan tyypin tiede". Useat länsimaat ovat tehneet siitä "kansakuntien valtapolitiikan ratkaisevan tekijän". Siksi kukaan tiedemies "ei voi välttää kysymystä: kuinka pitkälle hän haluaa liittyä sellaisten voimien kanssa, jotka uhkaavat koko ihmiskunnan olemassaoloa". (Max Born, Physics in My Generation, London 1956, s. 223)

Vetypommikokeiden aiheuttaman radioaktiivisen saastelaskeuman tultua tunnetuksi Russell uudisti vetoomuksensa. Russell puhui jouluaaton aattona 1953 BBC:ssä ydinsodan vaarasta. Vaikutus oli maailmanlaajuinen. Radiopuheensa pohjalta Russell laati manifestin, jonka hän lähetti maailman johtaville luonnontieteilijöille. Albert Einstein allekirjoitti sen kaksi päivää ennen kuolemaansa. Kun Russell julkaisi (sittemmin Russell-Einstein manifestina tunnetun vetoomuksen) lehdistötilaisuudessa Lontoossa heinäkuussa 1955 sen oli allekirjoittanut lisäksi 8 muuta maailmankuulua tiedemiestä, heidän joukossaan nobelistit Frederick Joliot-Curie, Max Born, Linus Pauling. Manifestis- 
sa selostettiin niitä vaaroja, joita vetypommin kehittäminen ja hillitön ydinvarustelukilpa toisi ihmiskunnalle, kehotettiin hallituksia etsimään rauhanomaisia ratkaisukeinoja konflikteihin ja ehdotettiin, että maailman johtavat tiedemiehet kokoontuisivat tutkimaan ydinasekilvan hillitsemismahdollisuuksia. (Muita tärkeitä kirjoituksia tuohon aikaan olivat mm. Albert Einstein, "Why Socialism?", Monthly Review June 1955; Linus Pauling, No More War, London 1956; J. Robert Oppenheimer, Thy Flying to Peace Three Crises for Physicists, London 1964; F. Joliot-Curie, Wissenschaft und Verantwortung, Berlin 1962.)

Manifestissa ehdotettu kokous saatiin erinäisten vaikeuksien jälkeen koolle Pugwashin kylään. Kokous onnistui hyvin, ja aloitettua työtä jatkamaan ja johtamaan kokouksessa muodostettiin ns. jatkavaisuustoimikunta. Sen jäseniksi valittiin B. Russell (Englanti), D.V. Skobeltsyn (Neuvostoliitto), E. Rabinovich (USA), C. Powell (Englanti) ja J. Rotblat. Rotblat toimi aluksi liikkeen pääsihteerinä. (Ks. tarkemmin B. Russell, The Early History of the Pugwash Movement, kirjassa Disarmament: Its Politics and Economics, Ed. by Seymour Melman, Boston 1962; J. Rotblat: History of the Pugwash Conferences, Science and World Affairs, London 1962; J. D. Bernal, Science in History, Volume 4, s. 1163-65.)

Pugwashin historia on olennaisesti sen järjestämien kokousten historiaa. Konferensseja järjestetään noin kerran vuodessa. Lisäksi liike on järjestänyt vuodesta 1968 lähtien myös suppeampia, vain yhtä teemaa käsitteleviä symposiumeja.

Kokoukset kutsuu koolle liikkeen johtokunta (entinen jatkavaisuustoimikunta), johon kuuluu nykyään 23 jäsentä (USA ja Neuvostoliitto 3, Englanti 2 jne.). Vuonna 1975 johtokuntaan valittiin prof. Jorma K. Miettinen (maaryhmän Suomi, Itävalta, Ruotsi, Sveitsi ja
Jugoslavia edustajana). Johtokunta myös valitsee konferenssien ja symposiumien osanottajat kansallisten Pugwash-toimikuntien suositusten perusteella. Kukaan ei siis voi itse ilmoittautua niihin. Kansallisia toimikuntia on nykyisin n. 25 maassa. Ne toimivat yleensä tiedeakatemioiden yhteydessä.

Kokouksia on järjestetty niin kapitalistisissa, sosialistisissa kuin kehitysmaissakin. Osanottajia on ollut vuosien varrella runsaat puoli tuhatta n. 60 maasta - eniten USA:sta, Neuvostoliitosta ja Englannista - , joukossa puolisensataa Nobelin palkinnon saajaa. Luonnontieteilijöillä on liikkeessä selvästi hallitseva asema, mutta viime aikoina myös yhteiskuntatieteilijöiden osallistuminen on vilkastunut.

Kokouksissa käytävä keskustelu on epävirallista ja se käydään suljettujen ovien takana mielipiteiden vaihdon edistämiseksi. Keskustelujen tuloksista olennaisimman liikkeen johtokunta ottaa ns. Pugwash-raporttiin, joka lähetetään $\mathrm{mm}$. hallitusten päämiehille, kansainvälisille järjestöille ja kaikille liikkeen jäsenille. Liike julkaisee myös neljästi vuodessa ilmestyvää "Pugwash Newsletter"-lehteä. (Ks. tarkemmin Jorma K. Miettisen artikkelit Aika 6/71 ja Kanava 3/73)

Wienissä 1958 pidetyn kolmannen konferenssin julkilausuma muodostaa edelleen eräänlaisen Pugwash-liikkeen aatteellisen julistuksen. Siinä todetaan mm.: "Sodat on lopetettava - ydinasein käytyä sotaa ei näet mikään valtio voi enää mielekkäällä tavalla voittaa. Kansainvälistä luottamusta on lisättävä varustelukilvan lopettamiseksi. Ydinkokeet on kokonaan lopetettava, aseidenriisunta on saatava tehokkaasti käyntiin. Lopullisesti kansojen turvallisuus saadaan taatuksi vain massatuhoaseet hävittämällä. Täydellinen tieteen vapaus on taattava kaikissa maissa esteetön tiedonvaihto ja vapaa matkustaminen ja maastamuutto sallittava. Tieteiden alalla tavallinen kansainvälisen yhteistyön traditio on toteutettava myös taloudellisella ja teknisellä alalla, ja aivan erityisesti kehitysmaissa. Tieteen epäterve salainen laajamittainen rahoitus sotilasbudjettien kautta lopetettava." Saadakseen käsityksen Wienin julkilausuman kannatuksen laajuudesta jatkuvaisuuskomitea lähetti sen n. 10000 kapitalististen maiden tiedemiehelle. Heistä n. $80 \%$ ilmoitti tukevansa julkilausuman näkemyksiä. Neuvostoliitosta ilmoitti 5000 tiedemiestä yhtyvänsä Wienin julkilausumaan. 10. Pugwash-konferenssissa 1962 Lontoossa hyväksytty julistus ja ohjelma täydentävät joiltakin osin Wienin julkilausumaa.

Mikä on sitten ollut Pugwashliikkeen merkitys? Pugwashille annetaan yleisesti suuri tunnustus $\mathrm{mm}$. vuoden 1958 ydinkoetauon ja vuoden 1963 osittaisen ydinkoekiellon valmistelujen aikaansaamisesta. Ydinsulkusopimuksen tarpeellisuutta ja ydinaseiden leviämisen estämistä on korostettu jatkuvasti liikkeen kokouksissa. Valkoisen talon ja Kremlin välinen "kuuma linja", ns. mustien rasioiden ("black box") käyttö maanalaisten ydinkokeiden toteamiseksi, avaruuden ydinaseettomuus ovat Pugwashin esittämiä. Kokouksissa on varoitettu taktisten ydinaseiden vaarallisuudesta. Ja viimeksi Pugwash-liike on tuominnut Yhdysvaltain päätöksen alkaa valmistaa neutronipommia.

Vuoden 1959 konferenssi keskittyi kemiallisten ja biologisten aseiden täydellisen kieltämisen edistämiseen, ja 1960-luvulla asia oli jatkuvasti esillä. Mm. Pugwashin ansiota oli, että NATO-maissa täysin salassa tapahtunut näiden aseiden uusin kehitys saatiin vedetyksi julkisen keskustelun piiriin. Liike vastusti myös USA:n Vietnamia vastaan käymää sotaa, tuomiten erityisesti USA:n käyttämät kemiallisen sodankäynnin menetelmät.

Vuodesta 1964 lähtien Pugwashin kokouksissa on käsitelty ns. SALT-neuvottelujen alaan liittyviä kysymyksiä. Liike on vaatinut lisäksi uusien asejärjestelmien kehit- 
tämisen estämistä ja sotilaallisen tutkimus- ja kehitystyön supistamista. Erityisesti 1970-luvulla konferensseissa on käsitelty Euroopan turvallisuusongelmia ja tuettu Euroopan turvallisuuskonferenssin järjestämistä. Myös Tukholman kansainvälinen rauhantutkimuslaitos (SIPRI) on perustettu Pugwashin herätteestä.

Jokseenkin kaikissa liikkeen kokouksissa on käsitelty tiedemiesten yhteiskunnallista vastuuta. Vastuu on pyritty kiteyttämään mahdollisimman johdonmukaiseksi "normistoksi". Mm. vuoden 1972 Lontoon kokouksen valmistelujen yhteydessä keskusteltiin siitä, voitaisiinko lääkäreiden "Hippokrateen valaa" laajentaa uudelleen muokkauksen jälkeen koskemaan kaikkia tiedemiehiä. (J. Kuczynski selostaa näitä keskusteluja kirjassaan Die vertauschte Minerva, teos kuuluu sarjaan Zur Kritik der bürgerlichen Ideologie, n:o 48.) Samaa asiaa käsiteltiin uudelleen 22. Pugwash-symposiumissa ("Tiede ja etiikka") 1975 Jugoslaviassa. Kokouksessa luovuttiin täsmällisen "normiston" muokkaamisesta. Yksimielisiä oltiin kuitenkin mm. seuraavista näkemyksistä:

- tiede ei ole arvovapaa, tiedettä ei voida irroittaa yhteiskunnallisesta käytännöstä;

- tiedemiehillä on suuri yhteiskunnallinen ja moraalinen vastuu;

- tieteellinen tutkimus ei saa vahingoittaa ihmisoikeuksia eikä biosfäärin herkkää tasapainoa;

- tieteellinen tutkimus on suunnattava sen, oman kehityksen edistämiseen ja ihmiskunnan perustarpeiden tyydyttämiseen;

- tiedemiesten tulee vaikuttaa tieteen tulosten soveltamiseen siten, ettei tieteen tulosten käyttö vahingoita nykyisen tai tulevien sukupolvien ihmisoikeuksia, saastuta ihmisen elinympäristöä tai luontoa, ettei tieteen tuloksia käytetä sodan ja tuhoaseiden kehittelyyn ja että tieteen tulokset palvelevat kaikkia kansoja ja yhteiskuntaryhmiä;

- tieteellisen yhteisön sisäiset suhteet ja suhteet yhteiskuntaan on järjestettävä niin, että ne edistävät tieteen rationaalista kehittämistä ja soveltamista, tukevat uusien tiedemiespolvien koulutusta, kunnioittavat kaikkien tiedemiesten oikeuksia ja ajatusten ja informaation vapaata vaihtoa. (Ks. tarkemmin General Conclusions of the 22nd Pugwash Symposium at Dubrovnik)

Suomalaisten tiedemiesten osanotto Pugwash-liikkeeseen on 1970-luvulla lisääntynyt. Vuonna 1970 Suomalainen Tiedeakatemia ja Suomen Tiedeseura asettivat yhteisen Pugwash-toimikunnan, jonka välityksellä maamme tiedemiesten osallistuminen liikkeen toimintaan tapahtuu. Toimikuntaan kuuluvat nykyään prof. Jorma $K$. Miettinen, prof. Bengt Broms, prof: Göran v. Bonsdorff ja prof. Keijo Korhonen. Kaikkiaan Pugwash-tilaisuuksiin on osallistunut $n$. 30 suomalaista. Prof. Miettinen on osallistunut erityisesti kemiallisen aseidenriisunnan ja taktisten ydinaseiden ongelmien käsittelyyn.

Liikkeen tilaisuuksia on Suomessa järjestetty kolme kertaa. 15 . Pugwash-symposium pidettiin Lahdessa elokuussa 1971. Sen aiheena oli Euroopassa olevien taktisten ydinaseiden vähentäminen. 23. Pugwashin vuosikonferenssi järjestettiin Lahdessa elosyyskuussa 1973 teemanaan "Euroopan turvallisuus, aseiden riisunta ja muut ongelmat". Tänä vuonna on järjestetty "arktinen" symposiumi. Lisäksi toimikunta on järjestänyt kaksi kansallista kokousta energiatuotannon (1975) ja väestönkehityksen (1976) ongelmista.

Pugwash-liikkeessä on ollut ja on edustettuina varsin erilaiset yhteiskunnallis-poliittiset katsomukset, ja luonnollisestikin yksimielisyyden saavuttaminen ei ole aina ollut helppoa. Liikettä sen nykyisessä vaiheessa voisi ehkä parhaiten kuvata aseidenriisunnasta kiinnostuneiden tiedemiesten YKtyyppiseksi järjestöksi. Ruimo Lovio johtajat.
SPONTAANIKSI PROTESTIKSI TUTKINNONUUDISTUKSEN saamaa vulgaaria ammatillistamissuuntaa vastaan voidaan tulkita yli sadan yliopistojemme yhteiskuntatieteen opettajan allekirjoittama adressi, joka jätettiin 5.5. opetusministeri Gestrinille. Allekirjoittajat vaativat $\mathrm{mm}$. tutkinnonuudistuksen lykkäämistä ja uudelleenarviointia. Protestin erikoisuus oli siinä, että sen allekirjoittajien joukko sisältää yksityishenkilöitä kaikista poliittisista piireistä. Selitys tälle erikoiselle yksimielisyydelle on lausunnolla oleva yhteiskuntatieteellisen alan tutkintoasetusluonnos, joka sisältää monia yhteiskuntatieteellisen koulutuksen ja sivistyksen kannalta tavattoman kriittisiä kohtia, ennen kaikkea lattean "ammatillistamisen" pyrkimyksen.

KORKEAKOULU JA TIEDEPOLIITTINEN TUTKIMUSSÄÄTIÖ KTTS JÄRJESTÄÄ KORKEAKOULUJEN ITSEHALLINTOSEMINAARIN 19.10.1977. Tilaisuuteen on kutsuttu melkoinen määrä Suomen korkeakouluväkeä. Onko tarkoituksena puolustaa korkeakoulujen itsehallintoa ja autonomiaa voimistuvia suurpääoman ja myös valtion vaikutuspyrkimyksiä vastaan?

Seminaarin alustajaluettelo antanee jonkinlaista osviittaa: Yhden suomalaisen yliopistomiehen (kansleri Hartiala Turusta) ja yhden kansainvälisen järjestön edustajan (pääsihteeri H.M.R. Keyes Kansainvälisestä yliopistojen liitosta) lisäksi alustavan puheenvuoron käyttää yksi opetusministeri, yksi budjettipäällikkö, yksi maaherra ja yksi kansliapäällikkö Suomesta sekä yksi tohtori OECD:stä. Valmisteltujen puheenvuorojen käyttäjien luettelossa ovat mukana $\mathrm{mm}$. Teollisuuden keskusliiton toimitusjohtaja, SAK:n puheenjohtaja sekä kunnallisliiton ja kaupunkiliiton 